\title{
Screening of Chickpea Germplasms against Meloidogyne incognita
}

\author{
Sulkshana Borah*, Aparajita Borah and Bornali Mahanta \\ Department of Nematology, Assam Agricultural University, Jorhat, Assam, India \\ *Corresponding author
}

\begin{tabular}{l} 
Ke y w or d s \\
$\begin{array}{l}\text { M. incognita, } \\
\text { Chickpea, } \\
\text { Germplasam, etc. }\end{array}$ \\
Article Info \\
\hline $\begin{array}{l}\text { Accepted: } \\
12 \text { October } 2020 \\
\text { Available Online: } \\
10 \text { November } 2020\end{array}$ \\
\hline
\end{tabular}

A B S T R A C T

\section{Introduction}

Chickpea (Cicer arietinum L.) belongs to the family leguminosae. It is an important pulse crop grown in India. Chickpea is one of the oldest pulses known and cultivated both in Asia and Europe. It is commonly known as gram or bengal gram. In India chickpea occupies an area of 96262000 ha and annual production of 93776000 tonnes with a productivity of $974 \mathrm{~kg} / \mathrm{ha}$ (Anon. 2017). In
India, the major chickpea production areas are situated in Madhya Pradesh, Rajasthan, Uttar Pradesh, Haryana, Maharashtra and Punjab. In Assam chickpea is grown in rabi season during the month of October and November. It occupies an area of 2193ha in Assam and annual production of 1544 tonnes with a productivity of $704 \mathrm{~kg} / \mathrm{ha}$ (Anon. 2017). Chickpea is mainly grown in 27 districts of Assam among which Dhubri, Dhemaji, Sonitpur, Jorhat and Lakhimpur are major 
districts. The crop chickpea suffers from a number of diseases which are caused by fungi, bacteria, virus and nematodes, which reduce the crop yield and retard plant vigour. Nematode not only suppresses the plant growth but also interferes in the nodulation, nitrogen fixation and adversely affects the overall yield.

Among different plant parasitic nematode, the root knot nematode, Meloidogyne incognita is considered to be one of the major limiting factors in the cultivation of chickpea which causes substantial loss in yield. It causes characteristics galls or knots on roots by which its infestation can be easily recognized. Besides causing direct damage to chickpea, Meloidogyne species also influences wilt inducing fungi (Mani, 1983) and bacterial nodulation (Koshy and Swarup, 1971). However, the amount of root galling generally depends on the level of Meloidogyne population density, host plant species and cultivar.

Severe nematode infections result in decreased yield of crops and deteriorate the marketable quality of the products. Several researchers have recommended the employment of resistant varieties is one of the cheap, primary, economically feasible and environmentally benign methods to combat root knot nematode as compared to nematicides (Darban et al., 2003, Tariq et al., 2013 and Sujatha et al., 2017). It has been found that root-knot nematodes may enter susceptible and resistant varieties of certain crops. Hence breaking of resistance in crop cultivars to root knot nematodes may occur naturally or by selection containing one or more resistant genes (Khan et al., 2000). The primary objective of the current research was to evaluate the available chickpea germplasms by screening method against root knot nematode $M$. incognita.

\section{Materials and Methods}

\section{Site and collection of germplasms}

A pot experiment was carried out in the net house of Department of Nematology, during the rabi season of 2016-17 to know the reaction of different germplasms of chickpea to Meloidogyne incognita. Twenty germplasms viz., JG-315, CSG-515, JG-16, JAKI-9218，RSG 991，GNG- 1958，GG-2, JG-14, Vijay, IPCK 02-29, L550, Vishwas, BG- 372, GNG-1581, BG-256, GNG-469, Annegiri 1, Vishal, HC-3, RSG-888 were obtain from the Director, IIPR, Kanpur. Five germplasms viz., JG62, ICCV10, JG 11, DCP and ICC313 were obtained from Department of Agricultural Biotechnology, Assam Agricultural University, Jorhat. Chickpea germplasm 'Avarodhi' was taken as susceptible check.

\section{Collection and preparation of soil media}

The soil used for pot experiments was collected from upland near to the Department of Nematology, Assam Agricultural University, Jorhat. Collected soil was mixed thoroughly and unwanted materials like stones, bricks, roots and foreign materials present were removed by sieving.

The soil was mixed with finely dried cowdung and river sand in the ratio of 2:1:1 and kept in shade. The soil mixture was moistened with required amount of water and sterilized in an autoclave at $121^{\circ} \mathrm{C}$ and $15 \mathrm{lb}$ pressure per square inch for half an hour. Earthen pots of $1 \mathrm{~kg}$ capacity of soil were cleaned and sundried.

Few broken pieces of bricks were placed at the bottom of the pots and filled with sterilized soil. Proper labelling of each pots was done with zinc plate. 


\section{Seed sowing and inoculation of juveniles}

Three seeds were sown in each pot filled with sterilized soil at a depth of $1 \mathrm{~cm}$ and then covered with a thin layer of soil. A little amount of water was sprinkled over the pots. Ten days after germination each seedling were inoculated with 500 freshly hatched second stage juveniles of Meloidogyne incognita. Each treatment was replicated five times. The pots were arranged in a Completely Randomised Design. Regular watering was done till harvesting of the crop. Insect pests when appeared were controlled by spraying insecticides.

\section{Observations}

Observations were recorded after forty five days of inoculation. For that plants were uprooted carefully. The entire root system was taken out from the pot and kept in a plastic bucket half filled with tap water. The number of galls and egg masses per root system were counted and recorded. Root-knot index for each germplasms was determined on the basis of root-knot index (1-5 scale) given by Sasser et al., (1984). Statistical analysis was performed by using WASP 1.0 software.

\section{Root-knot index (1-5 scale)}

\begin{tabular}{|c|c|c|}
\hline Scale & Particulars & Reactions \\
\hline $\mathbf{1 .}$ & No galls / eggmasses & Highly resistant (HR) \\
\hline $\mathbf{2 .}$ & $1-10$ galls / eggmasses & Resistant (R) \\
\hline $\mathbf{3 .}$ & $11-30$ galls / eggmasses & Moderately resistant (MR) \\
\hline $\mathbf{4 .}$ & $31-100$ galls / eggmasses & Susceptible (S) \\
\hline $\mathbf{5 .}$ & 101 and above galls / eggmasses & Highly susceptible (HS) \\
\hline
\end{tabular}

\section{Results and Discussion}

In the present investigation, the result revealed that all the germplasms showed varying degree of reaction to Meloidogyne incognita (Table 1 and Figure 1-6). Out of twenty five germplasms, two germplasms viz., 'VIJAY' and 'ICC-313' were found to be moderately resistant, nine germplasms viz., 'JAKI-9218', 'GNG-1958', 'GG-2', 'IPCK 02-29', 'L550', 'VISHWAS', 'BG-372', 'ANNEGIRI-1' and 'JG-11'were found to be highly susceptible and rest were found to be susceptible to Meloidogyne incognita. Pandey and Singh (1990) screened 16 chickpea (Cicer arietinum) varieties tested against $M$. incognita in pot experiments, only K1160 was resistant. T1 was moderately resistant while $\mathrm{K}$ 850, K 906, K 989, K 1150, K KPG 36 and KPG 59 were moderately susceptible. Rao and Krishnappa (1995) screened 13 cultivars (Annegiri-1, Chaffa, Radhey, H-208, L-550,
JG-62, Avarodhi, BEG-452, BDN-9-3, KCC4, Jyothi, ICC-37 and KCV-2) of chickpea were screened in a Meloidogyne incognita infested field at college farm, VAS, Bangalore and it was found that out of 13 cultivars screened, 11 varieties exhibited susceptible reaction while Annegiri-1 and Chaffa were found to be highly susceptible.

Jain and Trivedi (2000) screened 47 chickpea varieties, variety RSG 564 was found most susceptible to Meloidogyne incognita, developing the highest number of galls, eggs per egg mass and final nematode population in soil and variety RSG 617 was the least susceptible showing the lowest number of galls, egg masses, final nematode population in soil and the highest root and shoot length and weight. Haseeb et al., (2006) evaluated resistance in different cultivars of chickpea against Meloidogyne incognita under field conditions. 
Table.1 Reaction of different germplasms of chickpea against Meloidogyne incognita

\begin{tabular}{|c|c|c|c|}
\hline Sl. No. & Germplasms & Root-Knot Index $*(1-5)$ Scale & Reaction \\
\hline 1. & JG-315 & 3.2 & $\mathrm{~S}$ \\
\hline 2. & CSJ-515 & 3.6 & $\mathrm{~S}$ \\
\hline 3. & JG-16 & 3.4 & S \\
\hline 4. & JAKI-9218 & 4.4 & HS \\
\hline 5. & RSG-991 & 3.4 & $\mathrm{~S}$ \\
\hline 6. & GNG-1958 & 4.2 & HS \\
\hline 7. & GG-2 (GUJRAT GRAM) & 4.6 & HS \\
\hline 8. & JG-14 & 3.2 & $\mathrm{~S}$ \\
\hline 9. & VIJAY & 2.4 & MR \\
\hline 10. & IPCK-02-29 & 4.8 & HS \\
\hline 11. & L550 & 4.6 & HS \\
\hline 12. & VISHWAS & 4.8 & HS \\
\hline 13. & BG-372 & 4.4 & HS \\
\hline 14. & GNG-1581 & 3.6 & S \\
\hline 15. & $\mathrm{BG} 256$ & 3.8 & S \\
\hline 16. & GNG-469 & 3.4 & $\mathrm{~S}$ \\
\hline 17. & ANNEGIRI-1 & 4.8 & HS \\
\hline 18. & VISHAL & 3.2 & $\mathrm{~S}$ \\
\hline 19. & $\mathrm{HC}-3$ & 3.4 & S \\
\hline 20. & RSG-888 & 3.6 & $S$ \\
\hline 21. & JG-62 & 3.6 & S \\
\hline 22. & ICCV-10 & 3.2 & $\mathrm{~S}$ \\
\hline 23. & JG-11 & 4.4 & $\mathrm{HS}$ \\
\hline 24. & $\mathrm{DCP}$ & 3.4 & $\mathrm{~S}$ \\
\hline 25. & ICC-313 & 2.6 & MR \\
\hline \multirow[t]{2}{*}{26.} & AVARODHI (SC) & 4.8 & HS \\
\hline & $\begin{array}{l}\text { S.Ed( }( \pm) \\
\text { C.D } 0.05\end{array}$ & $\begin{array}{l}0.37 \\
0.74\end{array}$ & \\
\hline
\end{tabular}

$* 1=$ No disease intensity, MR = Moderately resistant, HS = Highly susceptible, $\mathrm{S}=$ Susceptible $\mathrm{SC}=$ Susceptible check, 5 = Maximum disease intensity

Fig.1 General view of pot experiment on chickpea

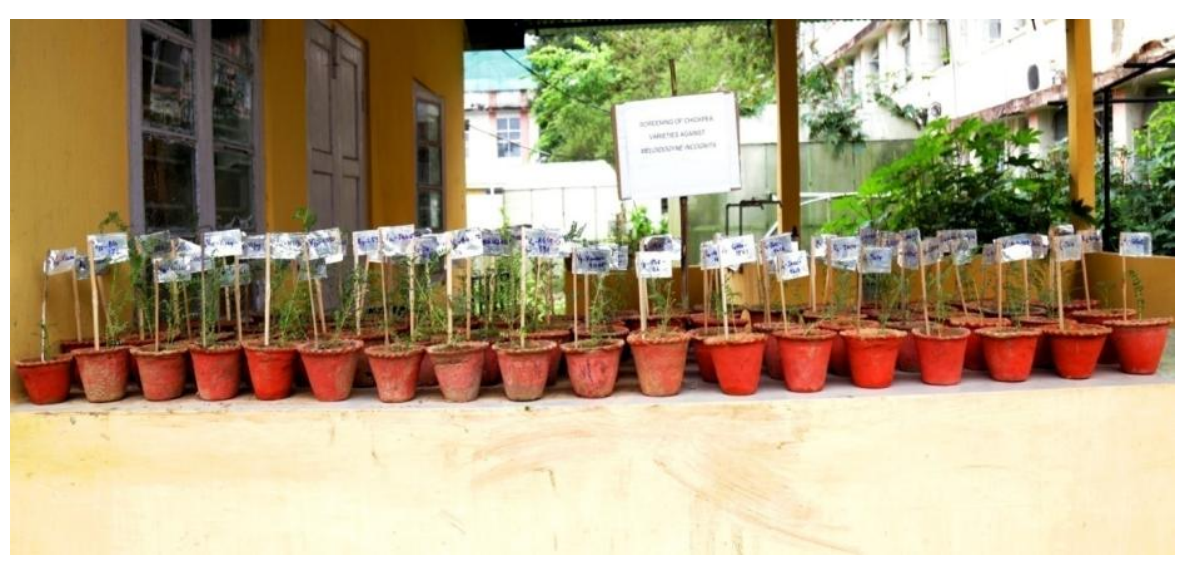


Fig.2 Screening of chickpea germplasms against Meloidogyne incognita
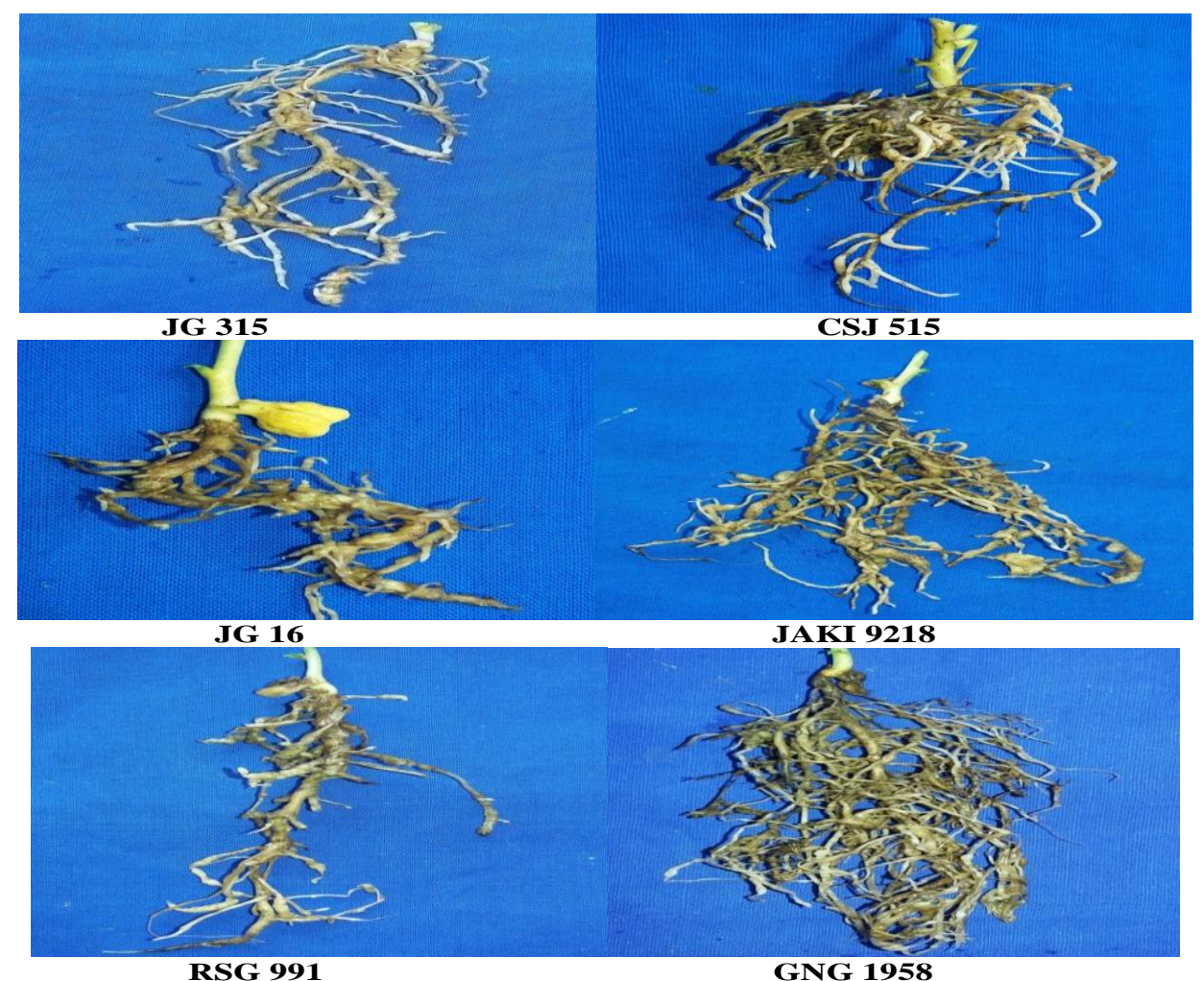

Fig.3 Screening of chickpea germplasms against Meloidogyne incognita
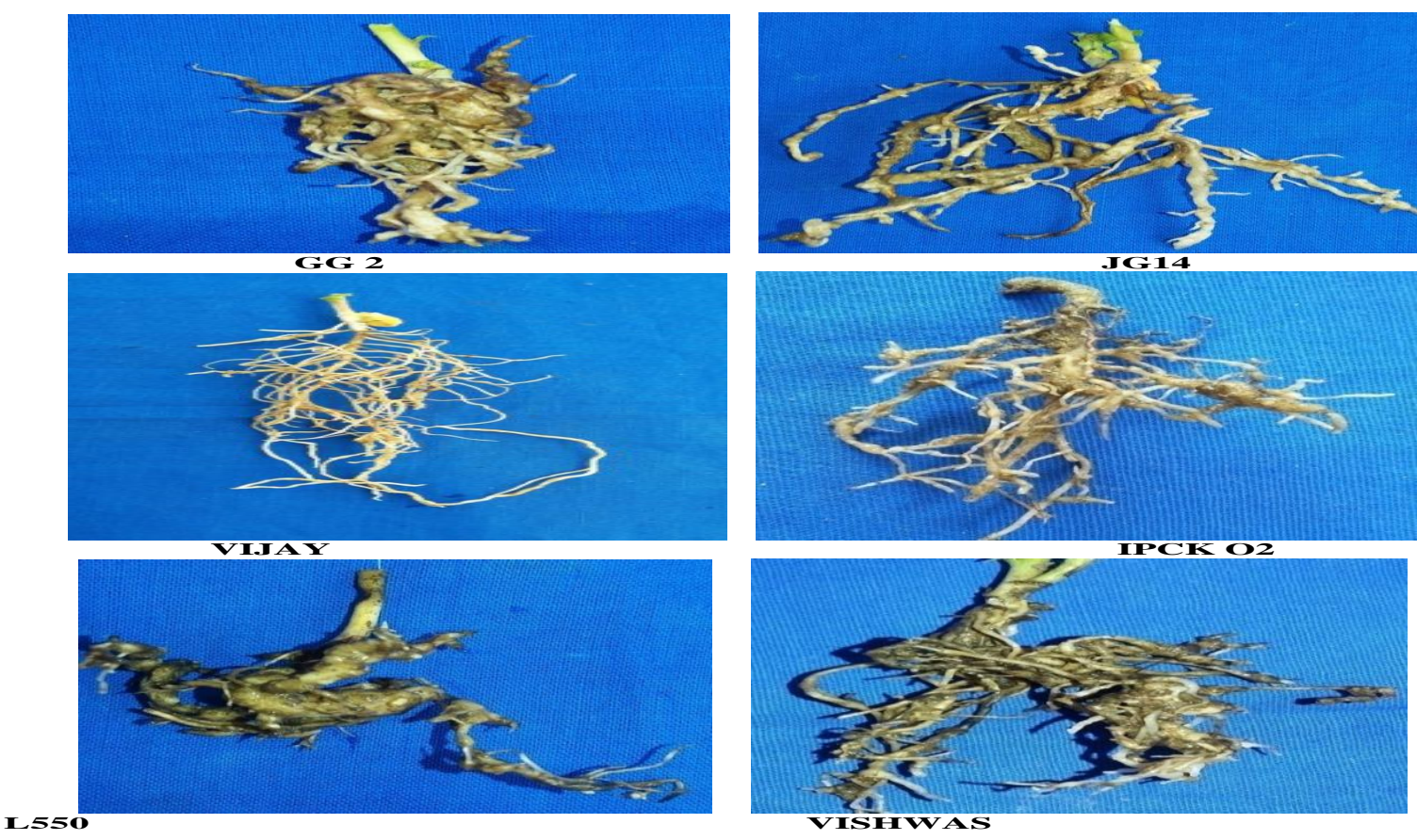
Fig.4 Screening of chickpea germplasms against Meloidogyne incognita
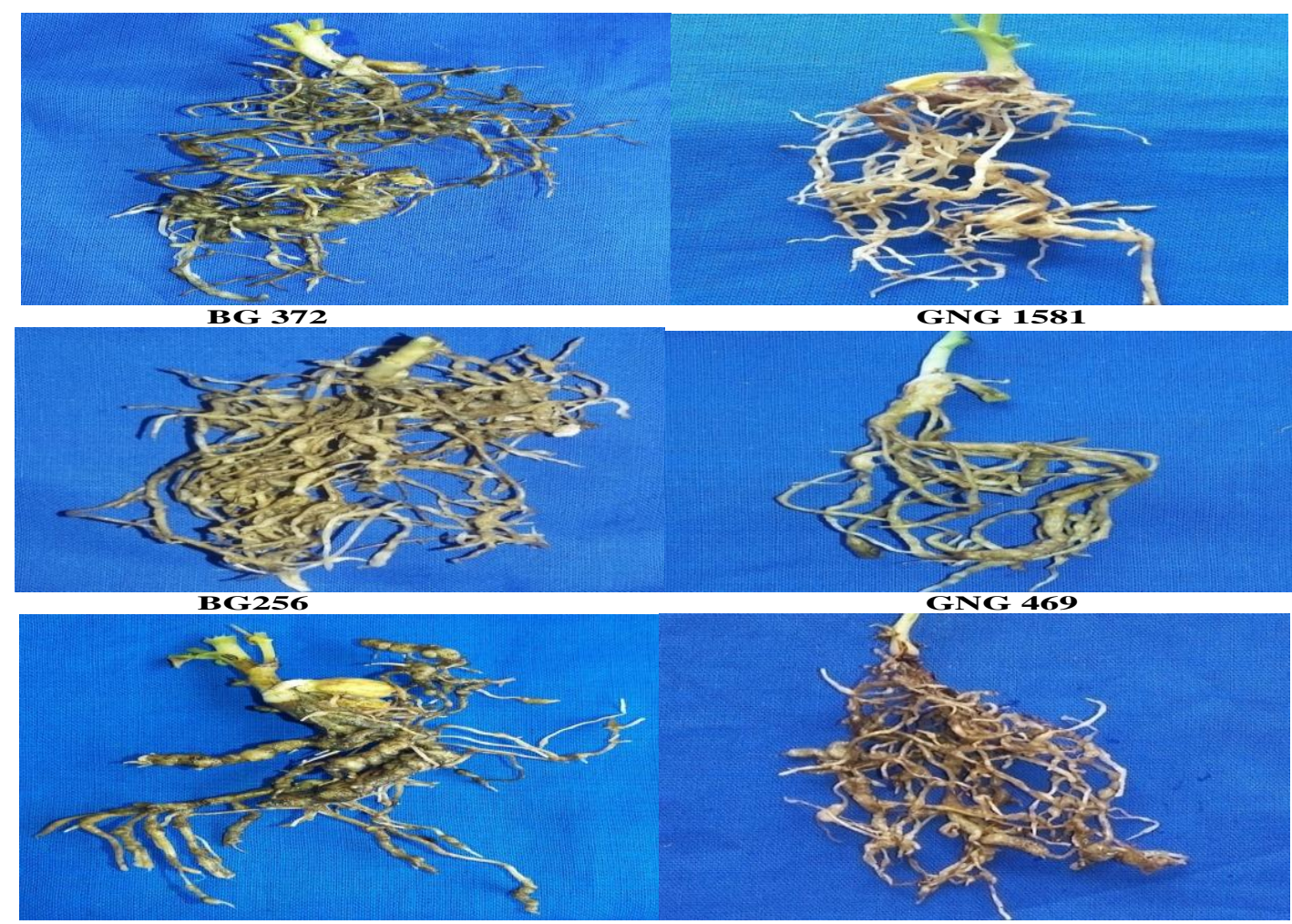

ANNEGIRI 1

GNG 1581
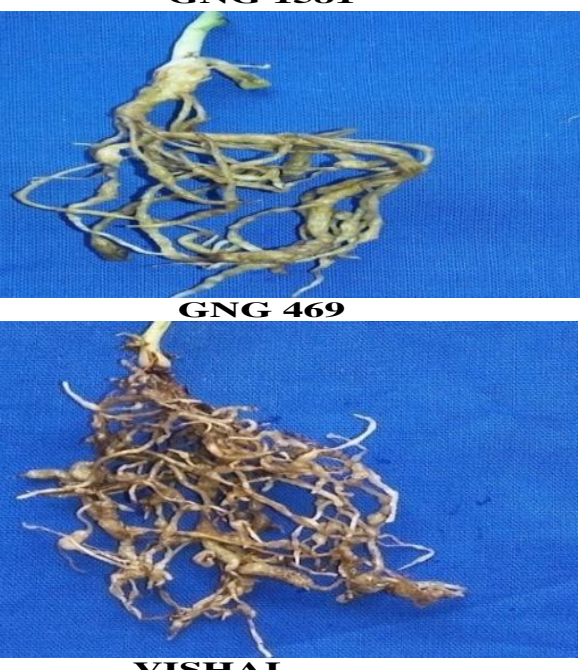

VISHAL

Fig.5 Screening of chickpea germplasms against Meloidogyne incognita
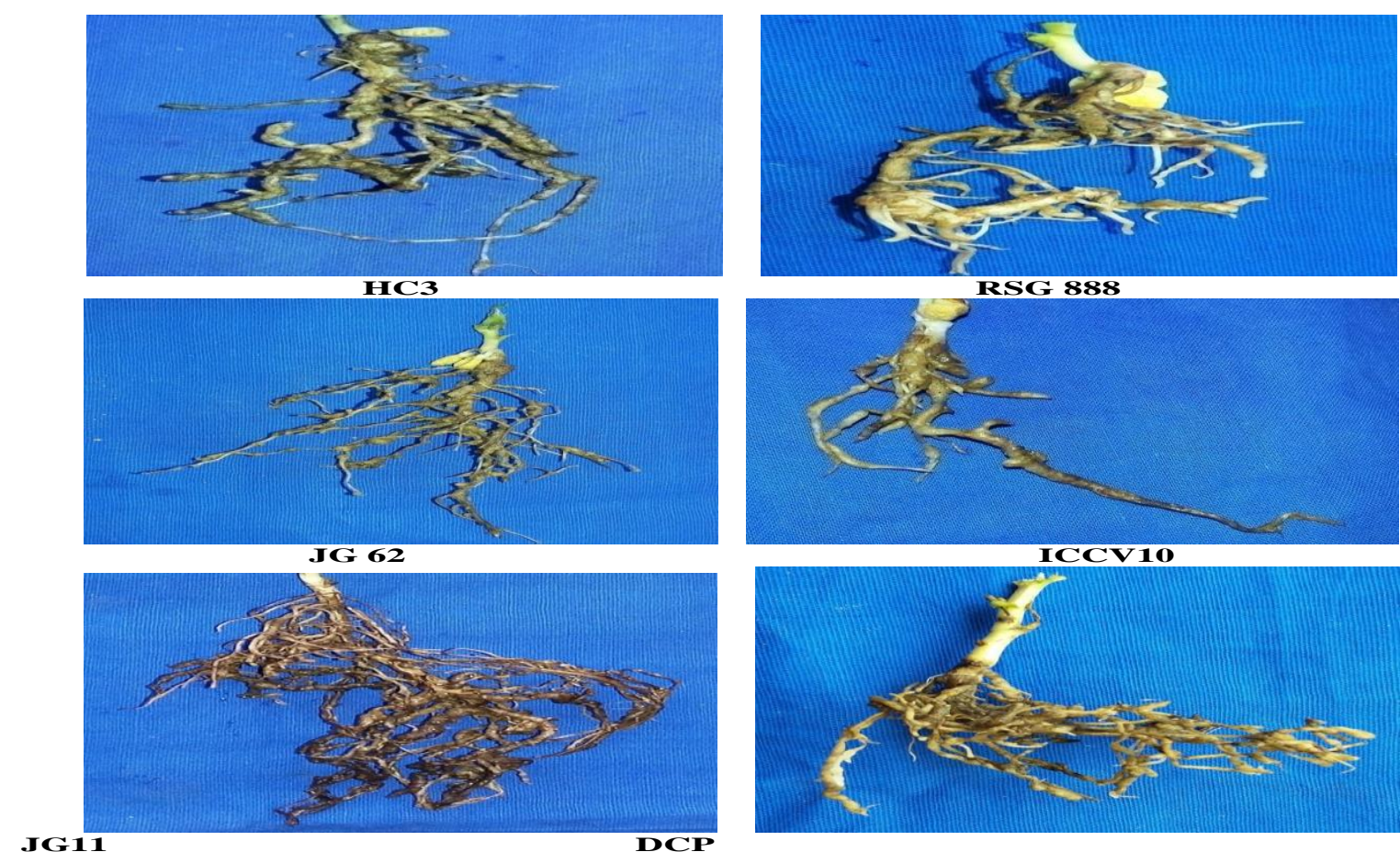
Fig.6 Screening of chickpea germplasms against Meloidogyne incognita

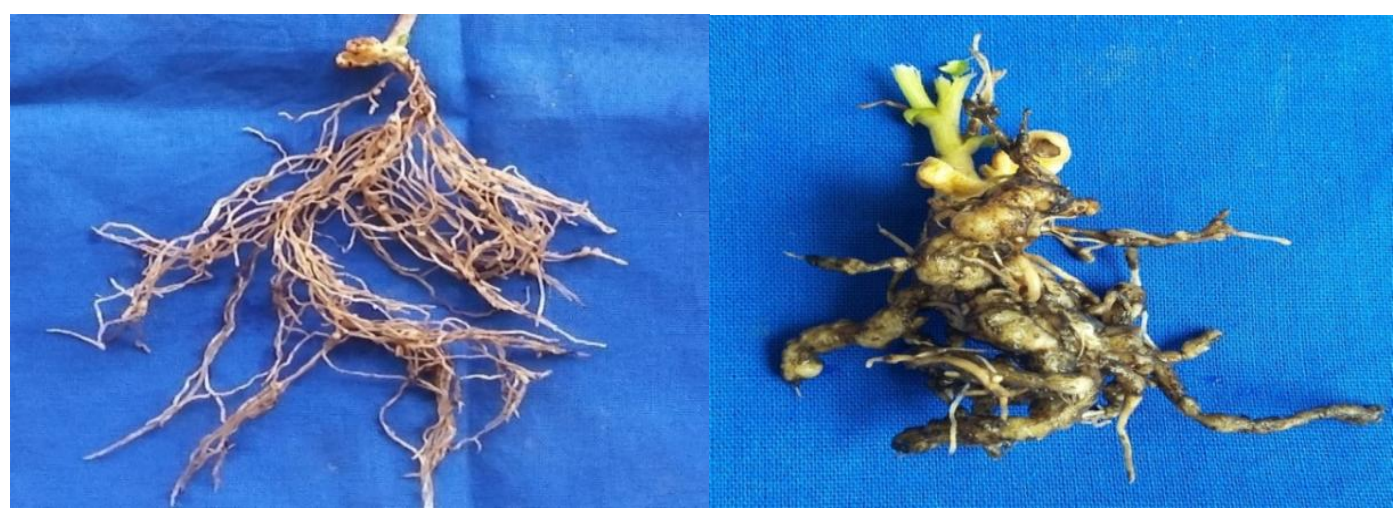

ICC313

None of the cultivars were highly resistant, whereas, Phule G-00108, Phule G-00109, Phule G-94259, Phule G-96006 and PDG-8416 were resistant and Phule G-00110, Phule G- 94091, H-82-2, IPCK-256, IPC-2001-02 and HR-00-299 were moderately resistant to M. incognita. Simon and Das (2010) screened 141 different varieties/ lines of chickpea out of 141 varieties of chickpea only 8 varieties were found moderately resistant, rest of the chickpea varieties were categorized highly susceptible and susceptible to $M$. incognita, none of the screened variety of chickpea were shown highly resistant and resistant. Chakraborty et al., (2016) screened 60 varieties of chickpea against $M$. incognita; out of which only nine varieties were recorded as resistant and rest were found to be either susceptible or highly susceptible.

\section{References}

Anonymous (2017). Directorate of Economics and Statistics. Department of Agriculture, Ministry of Agriculture, Govt. of India.

Chakraborty, S., Ghosh, M., Karmakar, P., Roy, D. and Samanta, P. (2016). Screening of some pulse germplasm for their reactions to rootknot nematode, Meloidogyne incognita (Kofoid and
AVARODHI

White) Chitwood G. Current Nematology. 27(2): 137-142.

Darban, D. A., Pathan, M. A., Jiskani, M. M., Wagan, K. H (2003). Response of some tomato cultivars to root-knot nematodes, Meloidogyne incognita. Pakistan Journal of Agriculture, Agricultural Engineering and Veterinary Sciences. 19:36-38.

Haseeb, A.; Sharma, A., Abuzar, S. and Kumar, V. (2006). Studied on Evaluation of resistance in different cultivars of chickpea against Meloidogyne incognita and Fusarium oxysporum f. sp. ciceri under field conditions. Indian Phytopathology. 59(2): 234-236.7.

Jain, C. and Trivedi, P.C. (2000). Varietal screening of Cicer arietinum against root knot nematode, Meloidogyne incognita. Indian Phytopath. 53(1):4953.

Khan, M. L and Nirupma, R. (2000). Screening of some tomato varietieslines for their resistance against Meloidogyne incognita in Himachal Pradesh. Indian journal of Nematology. 30:248-249.

Koshy, P. K. and Swamp, G. (1971). Distribution of Heterodera avenae, Heterodera zeae, Heterodera cajani 
and Anguina tritici in India. Indian $J$. Nematol. 1: 106-110.

Mani, A. (1983). Studies on the interaction or rootknot nematode, Meloidogyne incognita with Fusarium oxysporum f.sp. ciceri and Fusarium solani on chickpea. Indian Agricultural Research Institute, pp106.

Pandey, G. and Singh, K. P. (1990). Effect of organic amendments on soil microflora and nematode fauna with special reference to Meloidogyne incognita in chick pea. New Agriculturist. 1: 65-70.

Rao, V. K and Krishnappa, K. (1995). Indian Journal of Nematology Year, Reaction of some chickpea cultivars to Meloidogyne incognita in the field. Department of Plant Pathology, University of Agricultural Sciences, GKVK. 25(2): 217.

Sasser, J. N., Carter, C. C. and Hertonan, K. M. (1984). Standardization of Host suitability studies and reporting of resistance to root-knot nematode. Coop. Pula. Dept. Pl. Path. p. 7.

Simon, L.S. and Das, S. (2010). Screening of chickpea, field-pea, lentil and pigeonpea against root knot nematode, Meloidogyne incognita. Indian J. Nematol. 40(2): 231-233.

Sujatha, R., Vethamoni, P., Manivannan, N and Sivakumar, M. (2017). Screening of tomato genotypes for root knot nematode (Meloidogyne incognita Kofoid and White. Chitwood). International journal of current microbiology and applied science. 6(3): 1525-1533.

Tariq, M., Khan, T. A., Akhtar, G and Khan, N. (2016). Screening of Fenugreek (Trigonella foenum-Graecum) varieties against root-knot nematode Meloidogyne incognita Journal of plant pathology microbiology. 7(2): 335 .

\section{How to cite this article:}

Sulkshana Borah, Aparajita Borah and Bornali Mahanta. 2020. Screening of Chickpea Germplasms against Meloidogyne Incognita. Int.J.Curr.Microbiol.App.Sci. 9(11): 1636-1643. doi: https://doi.org/10.20546/ijcmas.2020.911.195 